\title{
Virological and bacteriological quality of drinking water in Ethiopia
}

\author{
Tesfaye Legesse Bedada ${ }^{1}$ - Walelign Dessie Mezemir ${ }^{2} \cdot$ Firehiwot Abera Dera ${ }^{1}$. Waktole Gobena Sima ${ }^{1}$. \\ Samson Girma Gebre ${ }^{1} \cdot$ Redwan Muzeyin Edicho ${ }^{1}$ - Almaz Gonfa Biegna ${ }^{1} \cdot$ Dejenie Shiferaw Teklu ${ }^{1}$. \\ Kassu Desta Tullu ${ }^{2}$
}

Received: 11 June 2017 / Accepted: 17 April 2018 / Published online: 24 April 2018

(c) The Author(s) 2018

\begin{abstract}
Since unsafe water is responsible for many illness, deaths, and economic failure, water quality monitoring is essential. A cross-sectional study was conducted on 218 drinking waters samples collected between February and June 2016 to assess water quality using phages by the help of CB390 E. coli host, plaque assay; multiple tube fermentation for coliforms and pour plate for heterotrophic bacteria at Ethiopian Public Health Institute. Heterotrophic plate count greater than $100 \mathrm{cfu} / \mathrm{ml}$ was noted in 41 samples and detections of total and thermotolerant coliforms and E. coli in 38, 24, and 10 samples, respectively, and no phages detection in chlorinated waters. While heterotrophic plate count greater than $100 \mathrm{cfu} / \mathrm{ml}$ was observed in 100 samples and detections of total and thermotolerant coliforms, E. coli, and phages in 75, 60, 42, and 5 samples, respectively, for untreated waters. The majority of the waters contained indicators above standard limits. This indicates that the sources are contaminated and they are potential threats for health. Hence, regular water monitoring should be a priority agenda.
\end{abstract}

Keywords Indicators $\cdot$ Drinking water $\cdot$ Coliforms $\cdot$ Coliphage

\section{Introduction}

Lack of safe water results in untold suffering, diseases, infant mortality, stunted growth, and economic loss (Pathak 2015). In developing countries, waterborne pathogens contribute $80 \%$ of health problems (Halvorson et al. 2010).

Since there is no universal indicator which has been identified (Skraber et al. 2004), testing of water using coliforms and coliphages would give a more complete picture of water quality. Due to cost constraints and the complexity of earlier coliphages methods, requiring testing for both indicators

Tesfaye Legesse Bedada

tesfayelegesse21@gmail.com

Walelign Dessie Mezemir

walelign.wa@gmail.com

Firehiwot Abera Dera

firehiwot_a@yahoo.com

Waktole Gobena Sima

wake22015@ gmail.com

Samson Girma Gebre girma.samson@gmail.com

Redwan Muzeyin Edicho rmuzeyin@gmail.com was previously not considered economically feasible (Salter 2012). Coliforms measure levels of fecal contamination in water distribution systems. They are facultative anaerobic, rod-shaped, Gram-negative bacteria, lactose fermenters, and produce acid and gas within $48 \mathrm{~h}$ at $35-37^{\circ} \mathrm{C}$ (Rompre et al. 2002). Since coliforms respond to environment and water treatments, much less similar, and they have larger size compared to viruses (Nkwe et al. 2015), they are not representative of viral contamination (Jurzik et al. 2010). Total coliforms are mainly used for the assessment of sanitary water quality after the water has been treated and disinfected.
Almaz Gonfa Biegna

algonfa@yahoo.com

Dejenie Shiferaw Teklu

dejenie21@gmail.com

Kassu Desta Tullu

kassudesta2020@gmail.com

1 Public Health Microbiology Research Team, Ethiopian Public Health Institute (EPHI), B. O. B: 1242, Addis Ababa, Ethiopia

2 Department of Medical Laboratory Science, CHS, School of Allied Health Science, Addis Ababa University, Addis Ababa, Ethiopia 
Thermotolerant coliforms are more closely related to fecal pollution. Escherichia coli is the most specific to fecal contamination (Odonkor and Ampofo 2013).

Another fecal contamination monitoring tools in drinking water are coliphages. Of two main groups of coliphages, male-specific coliphages are either DNA or RNA viruses that infect $E$. coli via pilli. Somatic coliphages are DNA viruses that infect bacterial hosts by direct attachment to cell walls (Dryden et al. 2006). Single-agar layer CB390 method reduces cost and workload to detect and quantify total coliphages in water (Price 2014).

A secondary indicator employed to evaluate water quality is heterotrophic plate count (HPC). Heterotrophic bacteria are aerobic and facultative anaerobic organisms. The large number of the bacteria may suggest the presence of opportunistic pathogens of non-fecal origin, which possibly indicate taste, odour, and corrosion problems in the water distribution system (Islam and Dey 2014). In Ethiopia, water quality is assessed using bacterial indicators. However, the use of coliphage has not been assessed; hence, we set and objective to determine the quality of drinking water using total coliphages, E. coli, thermotolerant and total coliforms, and heterotrophic bacteria in selected water samples in Ethiopia.

\section{Methods and materials}

A cross-sectional study was conducted on 218 drinking water samples at Public Health Microbiology Research Team Laboratory in Ethiopian Public Health Institute between February and June 2016. Water samples were collected from 92 treated and 31 untreated piped, 69 untreated wells, 13 untreated rivers, and 13 bottled drinking water samples from different locations of Addis Ababa, Oromia, Amhara, Afar and Southern Nations, Nationalities, and Peoples' Region (SNNPR) regional states of Ethiopia by trained professionals.

The study areas for pipes, wells, and rivers are located in central, northern, and southern Ethiopia that extend between latitude and longitude $8^{\circ} 00 \mathrm{~N}$ and $38^{\circ} 00 \mathrm{E}$, and present a diverse topography, ranging from $110 \mathrm{~m}$ below sea level to $4550 \mathrm{~m}$ above sea level.

The samples were collected into sterilized $500 \mathrm{ml}$ bottles and transported on ice to the laboratory. The Samples containing residual chlorine were neutralized by adding presterilized $0.5 \mathrm{ml}$ sodium thiosulphate per $500 \mathrm{ml}$ of water sample.

Carbon dioxide and filtration were the major treatment methods employed to inactivate or remove microbes in the carbonated bottled water industry and ultraviolet, ozone, and filtration for the non-carbonated water. Sampling site selection criteria were based on possible sources of contamination. Five units of the same batch of production of carbonated and uncarbonated bottled waters of eight brands produced in Ethiopia were collected to be analyzed as a single sample. Each bottle was thoroughly mixed to have an even distribution of microbes, and then, equal volume of the sample from each bottle of water was taken and mixed together to have a composite sample of the desired volume.

The samples were stored at $4{ }^{\circ} \mathrm{C}$. Microbiological investigations were performed within $24 \mathrm{~h}$ after collection. All samples were tested for HPC, total and thermotolerant coliforms, E. coli, male-specific, and somatic coliphages using standard methods (Price 2014; HACH 2012; Cheesbrough 2006); US Environmental Protection Agency 2001).

\section{Hpc assay}

One millilitre of each water sample was pipetted into the sterile petri dish. After thoroughly mixing, the melted plate count agar was poured into the dish. The melted medium was mixed thoroughly with the sample and let them solidify. The plates were incubated for $48 \mathrm{~h}$ at $35^{\circ} \mathrm{C}(\mathrm{HACH} 2012)$.

\section{Coliform assay}

The total coliform count test was based on the multiple tube fermentation method to estimate the most probable number (MPN) of total coliform, thermotolerant coliform and E. coli in $100 \mathrm{ml}$ of water. The test was carried out by incubating at $37{ }^{\circ} \mathrm{C}$ for $48 \mathrm{~h}$ in measured quantities of sample water (50,10, and $1 \mathrm{ml})$ into tubes of double and single-strength MacConkey broth (Difco). The tubes with acid and gas production were inoculated in brilliant green lactose bile broth to observe gas production after $48 \mathrm{~h}$ of incubation at $37^{\circ} \mathrm{C}$. Then, E. coli and nutrient broths were inoculated and incubated at $44.5^{\circ} \mathrm{C}$ for $48 \mathrm{~h}$ for gas production and indole test, respectively. The coliforms were estimated per $100 \mathrm{ml}$ of water using MPN tables (Cheesbrough 2006).

\section{Coliphages assay}

For the simultaneous detection of both types of male-specific and somatic Coliphages, single-agar layer plaque assay using coliphage host CB390 (obtained from University of North Carolina, Chapel Hill) log phase containing $0.15 \%$ ampicillin was applied with magnesium chloride in double-strength tryptic soy agar [Difco]. The coliphages were incubated for $16-24 \mathrm{~h}$ at $37^{\circ} \mathrm{C}$ and the plaques were enumerated. The coliphage counted was computed per $100 \mathrm{ml}$ of the sample (Price 2014; US Environmental Protection Agency 2001). 


\section{Data analysis procedures}

The data were entered, cleaned, and analyzed using SPSS 20 for Windows (SPSS Inc. Version 20, Chicago, Illinois). The Kruskall-Wallis test was used to find out the differences in indicators values by regions, water sources, and treatment types; and to observe the associations among the various indicators; the Spearman Rank Correlation was used to test the association between the variables. To check the normality of data, Shapiro-Wilk test was used. The significance level was set at $p$ value $<0.05$. The results were compared with established Ethiopian standards and WHO guidelines of drinking water.

\section{Results}

\section{Microbial quality of water samples}

Of the total 218 samples tested from various waters, heterotrophic bacteria, total and thermotolerant coliforms, $E$. coli, and total coliphages were detected in $72.9 \%(n=159)$, $51.8 \%(n=113), 38.5 \%(n=84), 23.9 \%(n=52)$, and $2.3 \%(n=5)$ of the samples, respectively. HPC $>100 \mathrm{cfu} /$ $\mathrm{ml}$ were observed in 141 (64.7\%) samples. High counts $\left(>3.0 \times 10^{2} \mathrm{cfu} / \mathrm{ml}\right)$ were found in $22.5 \%(n=49)$ of all samples for HPC; $>180 \mathrm{MPN} / 100 \mathrm{ml}$ in $17 \%(n=37)$ of the samples for total coliform and $11.5 \%(n=25)$ of the samples for thermotolerant coliforms.

Of the total water samples for chlorinated water samples, HPC $>100 \mathrm{Cfu} / \mathrm{ml}$ were observed in $41(18.8 \%)$ samples; detections of total and thermotolerant coliforms and E. coli in 38 (17.4\%), 24 (11.0\%), and 10 (4.6\%) samples, respectively, and no detection of coliphages. While, for untreated waters, HPC $>100 \mathrm{cfu} / \mathrm{ml}$ were observed in $100(45.9 \%)$ samples; detections of total and thermotolerant coliforms, E. coli, and coliphages in 75 (34.4\%), $60(27.5 \%), 42(19.3 \%)$, and $5(2.3 \%)$ samples, respectively. In all coliphage-detected samples, all indicators, heterotrophic bacteria, and coliforms were also detected, inversely in the absence of thermotolerant coliforms, there were no coliphages detections. The detections of heterotrophic bacteria, total coliforms, and thermotolerant coliforms by treatment status of water samples were shown in Tables 1, 2, and 3 .

Rho values of HPC, and total and thermotolerant coliforms to coliphages were $0.202,0.232$, and 0.269 ; total and thermotolerant coliforms to HPC were 0.754 and 0.677 , respectively, and total coliforms to thermotolerant was 0.816. $p$ values for HPC, and total and thermotolerant
Table 1 Total heterotrophic bacteria counts in treated and untreated drinking water samples using pouring method in different regions of Ethiopia between February and June 2016

Table 2 Estimation of total coliforms in treated and untreated drinking water samples using MPN method in different regions of Ethiopia between February and June 2016

Table 3 Estimation of thermotolerant coliform in treated and untreated drinking water samples using MPN method in different regions of Ethiopia between February and June 2016

\begin{tabular}{llllllll}
\hline Type of water & \multicolumn{7}{l}{ Heterotrophic plate count $(\mathrm{cfu} / \mathrm{ml})$} \\
\cline { 2 - 8 } & $<1$ & $1-100$ & $101-200$ & $201-300$ & $>300$ & Total & $\%$ \\
\hline Chlorinated & 41 & 10 & 26 & 6 & 9 & 92 & 42.2 \\
Unchlorinated & 8 & 5 & 50 & 10 & 40 & 113 & 51.8 \\
Bottled water & 10 & 3 & 0 & 0 & 0 & 13 & 6 \\
Total & 59 & 18 & 76 & 16 & 49 & 218 & 100 \\
$\%$ & 27.1 & 8.3 & 34.9 & 7.3 & 22.5 & 100 & 100 \\
\hline
\end{tabular}

\begin{tabular}{lllllll}
\hline Type of water & \multicolumn{7}{l}{ Total coliforms count $(\mathrm{MPN} / 100 \mathrm{ml})$} \\
\cline { 2 - 7 } & $<1$ & $1-10$ & $11-100$ & $101-180$ & $>180$ & Total \\
\hline Chlorinated & 4 & 16 & 14 & 3 & 5 & 92 \\
Unchlorinated & 8 & 18 & 23 & 2 & 32 & 113 \\
Bottled water & 13 & 0 & 0 & 0 & 0 & 13 \\
Total & 25 & 34 & 37 & 5 & 37 & 218 \\
\hline
\end{tabular}

\begin{tabular}{lllllll}
\hline Type of water & \multicolumn{7}{l}{ Thermotolerant coliforms (MPN/100 ml) } & & \\
\cline { 2 - 7 } & $<1$ & $1-10$ & $11-100$ & $101-180$ & $>180$ & Total \\
\hline Chlorinated & 68 & 21 & 2 & 1 & 0 & 92 \\
Unchlorinated & 53 & 23 & 11 & 1 & 25 & 113 \\
Bottled water & 13 & 0 & 0 & 0 & 0 & 13 \\
Total & 134 & 44 & 13 & 2 & 25 & 218 \\
\hline
\end{tabular}


coliforms and coliphages using Kruskall-Wallis test for the samples by region, source, and treatment type were $<0.05$.

\section{Bacteriological and virological indicator detection in treated water sources}

Of chlorinated drinking waters, 41(44.6\%) samples had HPC $>100 \mathrm{cfu} / \mathrm{ml}$ and 38 (41.3\%), 24 (26.1\%), and 10 (10.9\%) samples were positive for total and thermotolerant coliforms and E. coli, respectively, and no detection of coliphages. All eight brands of 13 bottled drinking water samples in Addis Ababa $(N=4)$ and Oromia $(N=9)$ had HPC $<100 \mathrm{cfu} / \mathrm{ml}$; total and thermotolerant coliforms and $E$. coli of $<1 \mathrm{MPN} / 100 \mathrm{ml}$ and coliphages of $<1 \mathrm{pfu} / 100 \mathrm{ml}$.

\section{Bacteriological and virological indicator in untreated waters}

Of untreated drinking waters, $100(88.5 \%)$ samples had HPC $>100 \mathrm{cfu} / \mathrm{ml}$ and 75 (66.4\%), 60 (53.1\%), 42 (37.2\%), and $5(4.4 \%)$ samples were positive for total and thermotolerant coliforms, E. coli, and coliphages, respectively. Untreated waters had HPC ranging from $100 \%$ for river to $80.6 \%$ for untreated piped water, total coliforms ranging from $92.3 \%$ for rivers to $60.9 \%$ for wells, thermotolerant coliforms ranging from $92.3 \%$ for rivers to $45.1 \%$ for piped waters, E. coli ranging from $84.6 \%$ for rivers to $29 \%$ for wells, and coliphages ranging from $38.5 \%$ for rivers to no detection for piped and well waters.

Of unchlorinated piped waters, $25(80.6 \%)$ samples had HPC $>100 \mathrm{cfu} / \mathrm{ml} ; 21$ (67.7\%), 14 (45.1\%), and 11 (35.5\%) samples were positive for total and thermotolerant coliforms and $E$. coli, respectively and no detection of coliphages in the samples.

Of unchlorinated wells, $62(89.9 \%)$ samples had HPC $>100 \mathrm{cfu} / \mathrm{ml} ; 42$ (60.9\%) samples, 34 (49.3\%) samples, and 20 (29\%) samples were positive for total and thermotolerant coliforms and E. coli, respectively and no detection of coliphages in the samples.

Of the rivers, all samples had HPC $>100 \mathrm{cfu} / \mathrm{ml}$ and 12 (92.3\%), 12 (92.3\%), $11(84.6 \%)$, and 5 (38.5\%) samples were positive for total and thermotolerant coliforms, E. coli, and coliphages respectively. The enumeration of coliphages analyzed in water samples from rivers were ranged between $2.2 \times 10^{1}$ and $5.3 \times 10^{2} \mathrm{pfu} / 100$.

\section{Discussion}

In the present investigation, virological and bacteriological quality of drinking water was assessed from various sources in Ethiopia. As expected, the majority of the samples (64.7\%) contained HPC above permissible limit of $>100 \mathrm{cfu} / \mathrm{ml}$ (WHO 2003) and total coliforms (51.8\%), thermotolerant coliforms (38.5\%), (23.9\%), and coliphages (2.3\%) above WHO guideline value of $<1 / 100 \mathrm{ml}$ (WHO 2011) of the total water samples. The presence of these indicators may not cause illness, but used as one of the indicators of pathogens that can cause intestinal infections, hepatitis, typhoid fever, and other illnesses (Emmanuel et al. 2009).

The findings observed in the present study about the incidences above the permissible limits of HPC and total coliforms in the total samples were lower than in some studies done on drinking water samples in Peshawar, Pakistan (80 and 70\%) (Ali et al. 2013) but higher than in one study in Pakistan (45 and 25\%) (Shar et al. 2010).

The presence of total coliforms in the chlorinated drinking water samples indicates a serious treatment failure; distribution system may be vulnerable to contamination (Ainsworth 2004; Health Canada 2010). Out of water samples positive for thermotolerant coliforms in the present study, $28.6 \%$ were treated drinking waters which indicate inadequate treatment and disinfection (Osman et al. 2011). The presence of $E$. coli in samples was more serious than other coliforms alone and possible presence of pathogens (Odonkor and Ampofo 2013).

The non-comply of $38.5 \%$ drinking water samples for thermotolerant coliforms is higher than the national survey, rapid assessment of drinking water quality in Ethiopia that tested drinking water quality for thermotolerant coliforms and found $28 \%$ of 1602 samples non-potable (Tadesse et al. 2010).

The finding observed in the present study about the presence of thermotolerant coliforms or $E$. coli above the recommended limits was comparable to similar study conducted in Bangladesh in various waters (Parvez et al. 2016) and lower than the study in India (100\% and 78.1\% (Borah et al. 2010). Though, in one study, the detections of these bacterial indicators were higher than that from Lithuania (16.7\%) (Malakauskas et al. 2007).

The detections above permissible limits for HPC, total and thermotolerant coliforms, E. coli, and coliphages in untreated water samples were 2.7 times, 2.0 times, 2.5 times, 4.2 times, and 4.4 times more than the detections for chlorinated water samples, respectively. The non-detection of coliphages in any treated water samples is consistent with the study done in the United States on ground water (Plummer et al. 2014).

Spearman correlation test indicated statistically significant positive correlations between coliphages and all other bacterial indicators and agreed with a study done in the United States on drinking water samples (Wu et al. 2011). HPC, and total and thermotolerant coliforms were strongly related to each other, though the non-parametric Kruskall-Wallis test showed that HPC, coliforms and total 
coliphages differed statistically by region, water source, and treatment type ( $p$ value $<0.05$ ).

In the present study, the non-compliance of samples collected from chlorinated piped water for thermotolerant coliforms was high (26.1\%) compared to $22.4 \%$ in survey of the same country. This might be due to the increment of sanitary risk factors such as lack of maintenance, leaks in piped water distribution system; poor site selection and failure to minimize sanitary risks (Tadesse et al. 2010).

All the 13 samples from the eight brands of bottled water contained $<100 \mathrm{cfu} / \mathrm{ml}$ for HPC and no detectable organism per $100 \mathrm{ml}$ for coliforms and coliphages. This good quality may be due to the current follow-up and enforcement of the bottled water companies to adhere to good manufacturing practice by the regulatory body. This is in consistent with the study done in Ghana (Addo et al. 2009) which found coliforms none detectable in any of the examined brands of bottled drinking waters.

Some investigations done in different countries have contained indicators in bottled drinking water. In Ethiopia, 325 bottled water samples of 11 domestic and two imported brands contained HPC above the permissible limits in 16.9\% of the samples (Tafere et al. 2014). In India, Jaipur city, 40 samples of various brands of bottled drinking water were tested for HPC, total coliforms and E. coli reported 50, 45, and 20\%, respectively (Gangil et al. 2013). In study done in Dar es Salaam, on 13 brands of 130 bottled drinking water, 92\% was reported HPC, $4.6 \%$ total coliforms, and 3.6\% thermotolerant coliforms (Kassenga 2007).

As expected, HPC non-compliance for treated piped water was lower than untreated water sources. Non-compliance of thermotolerant coliforms for treated piped water in Addis Ababa was lower than non-compliance in Oromia piped water but consistent with the previous national survey of RADWQ (Tadesse et al. 2010).

Large non-comply of untreated water sources for HPC (88.5\%), total coliforms (66.4\%), thermotolerant coliforms (53.1\%), E. coli (37.2\%), and total coliphages (4.4\%) signified the suggestion of WHO which states that surface water or shallow ground water should not be used as a source of drinking water without sanitary protection or treatment (WHO 2011).

The contamination of HPC and coliforms in untreated piped water was higher than that of treated piped water. The presence of $E$. coli in untreated piped water $(35.5 \%)$ was 3.3 times higher than in treated piped water samples. The detections of total and thermotolerant coliforms and E. coli in $60.9,49.3$, and $29 \%$, respectively, in wells were lower than studies done in Saudi Arabia (100\% total coliform, $87.88 \%$ thermotolerant coliforms) (Al Otaibi 2009) and Nigeria (100\% total coliform and 65\% E. coli) (Nwachukwu and Ume 2013). On the other hand, in some studies, the detections of total and thermotolerant coliforms and E. coli were higher than that from Turkey (25\% total coliform, $17.5 \%$ thermotolerant coliforms and 15\% E. coli (Aydin 2007).

Thermotolerant coliforms in protected dug wells (49.3\%) were higher than untreated and treated piped waters and comparable with the previous study in Ethiopia (Tadesse et al. 2010). Non-compliance of thermotolerant coliforms in Addis Ababa protected dug wells (33.3\%) and Oromia protected dug wells $(54.9 \%)$ was higher than the previous study in Ethiopia (25\%) for both regions (Tadesse et al. 2010). This level of contamination may be due to a source of contamination which is nearby; otherwise, groundwater sources are usually bacteriologically safe (Nkwe et al. 2015).

The non-compliance of HPC, total and thermotolerant coliforms, E. coli, and total coliphages in 100, 92.3, 92.3, 84.6 , and $38.5 \%$, respectively, in rivers indicates that they are the most contaminated sources and unfit for consumption. This poor quality of the source was consistent with the study done in Kathmandu Valley, Nepal (Haramoto et al. 2011). Rivers samples in SNNPR were more contaminated with the indicators than river samples in Oromia in the present study. The presences of coliphages in the rivers indicate the presence of enteric viruses (Plummer et al. 2014).

\section{Conclusion}

This study assessed bacterial and viral quality of drinking water sources in some regions of Ethiopia. Majority of the waters, mainly untreated sources contained bacterial indicators and rivers contained viral indicators above the standards permissible limits. This indicated that drinking waters are contaminated with environmental and fecal contaminants which are potential threats for human health, and probably, some of the waters sources may be unsafe for human consumption. This shows the high risk of infection for consumers and calls for immediate action. We recommend regular microbiological assessment and strengthening the water treatment system will reduce the risk of communicable diseases.

Open Access This article is distributed under the terms of the Creative Commons Attribution 4.0 International License (http://creativeco mmons.org/licenses/by/4.0/), which permits unrestricted use, distribution, and reproduction in any medium, provided you give appropriate credit to the original author(s) and the source, provide a link to the Creative Commons license, and indicate if changes were made.

\section{References}

Addo KK, Mensah GI, Donkor B, Bonsu C, Akyeh ML (2009) Bacteriological quality of bottled water sold on the Ghanaian market. AJFAND 9:1378-1387 
Ainsworth R (2004) Safe piped water: managing microbial water quality in piped distribution systems. IWA Publishing, London, UK

Ali J, Ullah N, Ali KF, Rahman Z, Ahmad I, Hassan S, Ahmad I (2013) Bacteriological quality analysis of drinking water of rural areas of Peshawar, Pakistan. Am Eur J Agric Environ Sci 13(9):1202-1206

AlOtaibi ELS (2009) Bacteriological assessment of urban water sources in Khamis Mushait Governorate, southwestern Saudi Arabia. Int J Health Geogr. https://doi.org/10.1186/1476-072X-8-16

Aydin A (2007) The microbiological and physico-chemical quality of groundwater in West Thrace, Turkey. Pol J Environ Stud $16: 377-383$

Borah M, Dutta J, Kumar Abani, Misra AK (2010) The bacteriological quality of drinking water in Golaghat Sub-division of Golaghat District, Assam, India. Int J Chemtech Res 2:1843-1851

Cheesbrough M (2006) District laboratory practice in tropical countries, 2nd edn. Cambridge University Press, Cambridge

Dryden SK, Ramaswami B, Yuan Z, Giammar DE, Dryden SK, Angenent LT (2006) A rapid reverse transcription-PCR assay for F+ RNA coliphages to trace fecal pollution in Table Rock Lake on the Arkansas-Missouri Border. Water Res 40:3719-3724

Emmanuel E, Pierre MG, Perrodin Y (2009) Groundwater contamination by microbiological and chemical substances released from hospital wastewater and health risk assessment for drinking water consumers. Environ Int J 35:718-726

Gangil R, Tripathi R, Patyal A, Dutta P, Mathur KN (2013) Bacteriological evaluation of packaged bottled water sold at Jaipur city and its public health significance. Vet World 6:27-30

HACH (2012) Standard Methods for the examination of water and wastewater: method 9215 B, Pour Plate Method. HACH, USA

Halvorson SJ, Williams AL, Ba S, Dunkel FV (2010) Water quality and water borne disease in the Niger River Inland Delta, Mali: a study of local knowledge and response. Health Place 17:449-457. https ://doi.org/10.1016/j.healthplace.2010.10.002

Haramoto E, Yamada K, Nishida K (2011) Prevalence of protozoa, viruses, coliphages and indicator bacteria in groundwater and river water in the Kathmandu Valley. Nepal RSTMH 105:711-716

Health Canada (2010) Canadian drinking water guidelines. Health Canada, Ottawa, ON. http://www.hc-sc.gc.ca/ewh-semt/water-eau/ drink-potab/guide/index-eng.php. Accessed 10 Mar 2016

Islam MS, Dey SK (2014) Designing of culture media for increased recovery of total heterotrophs from water samples. IJIMS 1:147153. http://www.ijims.com. Accessed 10 Mar 2016

Jurzik L, Hamza IA, Puchert W, Überla K, Wilhelm M (2010) Chemical and microbiological parameters as possible indicators for human enteric viruses in surface water. Int J Hyg Environ Health 213:210-216

Kassenga GR (2007) The health-related microbiological quality of bottled drinking water sold in Dar es Salaam, Tanzania. J Water Health 5:179-185

Malakauskas M, Kasnauskytė N, Kudirkienė E, Šernienè L, Malakauskas A, Stimbirys A, Milius J (2007) Microbiological evaluation of drinking water from centralized and small community supply systems in Kaunas region, Lithuania. Vet Med Zoot 38:50-56

Nkwe KI, Ateba CN, Sithebe NP, Bezuidenhout CC (2015) Enumeration of somatic and F-RNA phages as an indicator of fecal contamination in potable water from rural areas of the North West Province. Pathog 4:503-512

Nwachukwu E, Ume CA (2013) Bacteriological and physicochemical qualities of drinking water sources in local area of Eastern Nigeria. J Soc Social Work Res 2:336-341
Odonkor ST, Ampofo JK (2013) Escherichia coli as an indicator of bacteriological quality of water-an overview. Microbiol Res 4:5-11

Osman GA, Kamel MM, Hassan HM, Al-Herrawy AZ (2011) Microbial quality of nile water and drinking water in some areas of Greater Cairo. Egypt Aust J Basic Appl Sci 5(11):1328-1334

Parvez AK, Liza SM, Marzan M, Alvee Ahmed A, Rahman MS (2016) Bacteriological quality of drinking water samples across Bangladesh. Arch Clin Microbiol 7:1

Pathak H (2015) Effect of water borne diseases on indian economy: a cost- benefit analysis. An Rom Sov Ser Med Gen 1:74-78

Plummer JD, Long SC, Liu Z, Charest AA (2014) Torque Teno virus occurrence and relationship to bacterial and viral indicators in feces, wastewaters, and waters in the United States. J Environ Health Sci 31:671-680

Price MT (2014) Comparison of Single-Agar Layer and two-step enrichment spot plate methods in the detection of somatic and male-specific coliphages in NC type II reclaimed water samples. Master's thesis, University of North Carolina, Chapel Hill, NC

Rompre A, Servais P, Baudart J, De-roubin MR, Laurent P (2002) Detection and enumeration of coliforms in drinking water: current methods and emerging approaches. J Microbiol Methods 49:31-54

Salter R (2012) Testing drinking water for coliphage as a fecal quality indicator: advances in rapid coliphage detection. Charm Sciences, Westbrook

Shar AH, Kazi YF, Kanhar NA, Soomro IH, Zia SM, Ghumro PB (2010) Drinking water quality in Rohri City, Sindh, Pakistan. Afr J Biotechnol 9:7102-7107

Skraber S, Gassilloud B, Gantzer C (2004) Comparison of coliforms and coliphages as tools for assessment of viral contamination in river water. Appl Environ Microbiol 70:3644-3649

Tadesse D, Desta A, Geyid A, Girma W, Fisseha S, Schmoll O (2010) Rapid assessment of drinking water quality in the federal democratic republic of Ethiopia. WHO and UNICEF, Geneva, Switzerland

Tafere W, Abera F, Beyene Y, Legesse T (2014) Microbiological quality and safety of bottled water brands sold in Ethiopia. Ethiop J Health Dev 28:178-184

US Environmental Protection Agency (2001) Method 1602: malespecific $\left(\mathrm{F}_{-}\right)$and somatic coliphage in water by single agar layer (SAL) procedure. EPA document 821-R-01-029. Environmental Protection Agency, Washington

WHO (2003) Heterotrophic plate counts and drinking-water safety: the significance of HPCS for water quality and human health. WHO Health Organization, UK

WHO (2011) Guidelines for drinking water quality, recommendations, 4th edn. World Health Organization, Switzerland

Wu J, Long SC, Das D, Dorner SM (2011) Are microbial indicators and pathogens correlated? A statistical analysis of 40 years of research. J Water Health 9:265-278

Publisher's Note Springer Nature remains neutral with regard to jurisdictional claims in published maps and institutional affiliations. 